\title{
Perceived Barriers of Physical Activity Participation in Individuals with Intellectual Disability-A Systematic Review
}

\author{
Miguel Jacinto ${ }^{1,2, *}$, Anabela Sousa Vitorino ${ }^{3,4}$, Diogo Palmeira ${ }^{5}$, Raul Antunes ${ }^{2,6,7}$ (D), Rui Matos ${ }^{2,6}$ (D), \\ José Pedro Ferreira ${ }^{1,8}$ (D) and Teresa Bento ${ }^{3,4}$ \\ 1 Faculty of Sport Sciences and Physical Education, University of Coimbra, 3040-248 Coimbra, Portugal; \\ jpferreira@fcdef.uc.pt \\ 2 Life Quality Research Centre (CIEQV), 2040-413 Rio Maior, Portugal; raul.antunes@ipleiria.pt (R.A.); \\ rui.matos@ipleiria.pt (R.M.) \\ 3 Sports Science School of Rio Maior, Polytechnic Institute of Santarém, 2040-413 Rio Maior, Portugal; \\ anabelav@esdrm.ipsantarem.pt (A.S.V.); teresabento@esdrm.ipsantarem.pt (T.B.) \\ 4 Research Center in Sport Sciences, Health Sciences and Human Development (CIDESD), \\ 5001-801 Vila Real, Portugal \\ 5 Faculty of Sport, Porto University, 4200-450 Porto, Portugal; diogopalmeira96@gmail.com \\ 6 School of Education and Social Sciences, Polytechnic Institute of Leiria, 2411-901 Leiria, Portugal \\ 7 Center for Innovative Care and Health Technology (ciTechCare), Polytechnic of Leiria, \\ 2410-541 Leiria, Portugal \\ 8 Research Center for Sport and Physical Activity (CIDAF), 3040-248 Coimbra, Portugal \\ * Correspondence: miguel.s.jacinto@ipleiria.pt
}

check for updates

Citation: Jacinto, M.; Vitorino, A.S.; Palmeira, D.; Antunes, R.; Matos, R.; Ferreira, J.P.; Bento, T. Perceived Barriers of Physical Activity Participation in Individuals with Intellectual Disability-A Systematic Review. Healthcare 2021, 9, 1521. https://doi.org/10.3390/ healthcare 9111521

Academic Editor: Robbert Gobbens

Received: 12 October 2021

Accepted: 4 November 2021

Published: 8 November 2021

Publisher's Note: MDPI stays neutral with regard to jurisdictional claims in published maps and institutional affiliations.

Copyright: (c) 2021 by the authors. Licensee MDPI, Basel, Switzerland. This article is an open access article distributed under the terms and conditions of the Creative Commons Attribution (CC BY) license (https:// creativecommons.org/licenses/by/ $4.0 /)$.

\begin{abstract}
Individuals with intellectual disability (ID) tend to have a sedentary lifestyle, with low physical fitness and an increased risk of chronic diseases. One reason for the prevalence of a sedentary lifestyle is the existence of barriers to participation in physical activity (PA). The purpose of this systematic review is to update knowledge about the perceived barriers of PA participation in individuals with ID. Electronic searches were carried out in the PubMed, Scopus, SPORTDiscus and Web of Science databases, from September 2020 to May 2021, and included articles published between January 2016 and May 2021. The terms used were: "mental retardation", "intellectual disability", "intellectual disabilities", "physical activity", "motor activity", "barriers", "obstacles", "embarrassment" and "constraint", in combination with the Boolean operators "AND" or "OR". After the methodological process, five studies were included for analysis. These studies revealed the existence of several perceived barriers to regular PA participation, which were grouped into five main groups: personal (6 topics), family (4 topics), social (13 topics), financial (1 topic) and environmental (1 topic). The knowledge and identification of participation barriers can be of extreme importance both to institutions and professionals aiming to enhance the participation of individuals with ID in regular PA programs.
\end{abstract}

Keywords: barriers; intellectual disability; interview; physical activity; sedentary lifestyle

\section{Introduction}

Intellectual disability (ID) is characterized by a deficit in intellectual and adaptive functioning in the conceptual, social and practical domain, being identified with deep, severe, moderate and mild degrees, developing before the age of 18 [1].

In this population, sedentary lifestyles prevail [2,3], not meeting the World Health Organization PA guidelines [4].

Due to their sedentary lifestyles, individuals with ID have low levels of physical fitness [5-7], with an increased risk of acquiring other comorbidities such as type II diabetes, hypertension, cholesterol and metabolic syndrome [8]. On the other hand, adopting a healthy active lifestyle and regular PA participation positively affect their physical 
ability (aerobic capacity, strength, balance and flexibility), cognition, health and quality of life [9-12].

One of the reasons found in the literature that can justify the fact that these individuals adopt sedentary lifestyles is the existence of barriers/obstacles/constraints that make the practice of PA difficult $[13,14]$.

Previous research has already mentioned the existence of these barriers, such as Bossink's study, which reported that there are 14 personal barriers and 23 environmental barriers to PA participation [13]. Additionally, and according to McGarty and Melville's study [14], the barriers to PA participation are associated with three main factors: (i) family members, (ii) personal factors and (iii) social factors.

Over the years, the barriers identified by these authors may have already been overcome and new ones may have emerged, and some of these studies are limited in time and fail to analyze other perspectives and perceptions rather than those expressed by family members.

For this reason, the purpose of the present systematic review is to contribute to a better understanding of the perceived barriers of physical activity participation in individuals with intellectual disability, analyze the reasons and the factors involved and to identify the main strategies to be used by professionals based on the perception of the different stakeholders (individuals with ID, their families or technical caregivers).

\section{Materials and Methods}

The systematic review was carried out in accordance with the PRISMA protocol $[15,16]$ and the methods suggested by Bento [17]. The protocol was registered in the INPLASY, with number INPLASY2021100092 (DOI:10.377667inplasy2021.10.0092). The PICOS strategy $[18,19]$ was defined in order to obtain a final sample of studies that: included participants (P) with ID (Down syndrome-DS included), of any age, gender, ethnicity or race; that intended to identify the effects of the perceived barriers to PA (I) on these individuals' participation in $\mathrm{PA}(\mathrm{O})$.

\subsection{Information Sources and Search Strategy}

Exploratory research was performed in the databases (from September 2020 to the 12 May 2021) in order to better understand the potential for this review and to define the research question and methodology to be used. The next day (13 of May 2021), an electronic search was carried out using the following databases: PubMed (all fields), SPORTDiscus, Web of Science and Scopus (article title, abstract and keywords), and this included the period between 2016, i.e., the end date of Bossink et al.'s [13] systematic review, and May 2021. The following search indexed descriptors were used in all databases: "mental retardation" (MeSH Terms), "intellectual disability" (MeSH Terms), "intellectual disabilities" (MeSH Terms), "physical activity" (MeSH Terms), "motor activity" (MeSH Terms), "barriers", "obstacles", "embarrassment" (MeSH Terms) and "constraint", in the following format: ("mental retardation" OR "intellectual disability" OR "intellectual disabilities") AND ("physical activity" OR "motor activity") AND ("barriers" OR "obstacles" OR "embarrassment" OR "constraint"). In the first phase, articles were organized and duplicates were identified and excluded using EndNote software. Subsequently, articles were analyzed and selected based on the fulfilment of the defined inclusion and exclusion criteria. In addition, the reference lists were revised and articles of interest were identified and included in the systematic search.

\subsection{Eligility Criteria}

To be included in the present systematic review, studies had to meet the following criteria: (i) full-text scientific publication in the English language; (ii) no restrictions regarding race or ethnicity; (iii) studies with any age group or gender; (iv) studies without restrictions on the number of participants; (v) studies that described the assessment instruments used; (vi) studies that clearly and objectively present the results related to the impact of potential 
barriers to PA participation in individuals with intellectual disability. The major exclusion criteria used in the study were the following: (i) review articles, comments, theses or abstracts published in minutes of congresses or conferences; (ii) individuals with pathologies other than ID and DS, such as, for example, autism, motor disabilities, hypertension, among others; (iii) studies with athletes registered in sports federations.

\subsection{Selection and Data Collection Process}

After completing the systematic search, duplicates were eliminated and all the articles that did not meet the inclusion criteria were removed. The studies selected in the previous phase were reviewed in their entirety by two independent reviewers (MJ and DP) according to the specific eligibility criteria. The main reviewer (MJ) identified the relevant information about each one of the studies and organized it in summary tables by: authorship, year of publication, country (origin of the research team), objectives, participants, type of study, evaluation techniques, main results/conclusions and quality of information index (see Table 1). After reading the full text of the studies, and according to the eligibility criteria previously defined, the study sample was constituted by five studies.

Table 1. Characteristics of the studies.

\begin{tabular}{|c|c|c|c|c|}
\hline $\begin{array}{l}\text { Author, } \\
\text { Reference, } \\
\text { Country }\end{array}$ & Aims & Participants & Type of Study & $\begin{array}{l}\text { Evaluation } \\
\text { Techniques }\end{array}$ \\
\hline $\begin{array}{c}\text { Alesi [20] } \\
\text { Italy }\end{array}$ & $\begin{array}{l}\text { Compare the } \\
\text { perceptions about } \\
\text { the practice of PA } \\
\text { between parents } \\
\text { of children with } \\
\text { and without DS. }\end{array}$ & $\begin{array}{c}19 \text { families of } \\
\text { individuals with DS } \\
\text { (children: } 10 \text { boys and } \\
9 \text { girls, } 20.94 Y \text { ); } \\
\text { Recruitment: support } \\
\text { institutions for people } \\
\text { with DS. }\end{array}$ & $\begin{array}{l}\text { Exploratory } \\
\text { study. }\end{array}$ & $\begin{array}{l}\text { Semi-structured } \\
\text { interview with } \\
\text { family members; } \\
\text { Maximum } \\
\text { duration of } \\
25 \text { min. }\end{array}$ \\
\hline
\end{tabular}

\begin{tabular}{|c|c|}
\hline $\begin{array}{c}\text { Cartwright } \\
\text { et al. [21] }\end{array}$ & $\begin{array}{l}\text { Analyze the } \\
\text { perspectives of } \\
\text { individuals with }\end{array}$ \\
\hline $\begin{array}{l}\text { United } \\
\text { Kingdom }\end{array}$ & $\begin{array}{l}\text { ID and their } \\
\text { caregivers } \\
\text { about PA. }\end{array}$ \\
\hline
\end{tabular}

et al. [22]

United

Kingdom
$\mathrm{N}=42$ (12 individuals who were part of the project, 10 family

members, 10 technical caregivers and

10 individuals with

ID); Recruitment: day

centres in Scotland.
Semi-structured interviews, with different questions for the

4 groups.
Barriers to PA Practice

Quality

Score

Lack of technical specialists in adapted PA; Lack of adapted PA programs; Lack of inclusive programs;

Characteristics of the disability itself (physical, physiological and psychological):

Parent's preoccupation;

Lack of time for parents to engage in PA with their children; Transport difficulties (high costs, lack of transport);

Limitation on economic resources.

Acceptance of the inactive lifestyle of people with ID_technical caregivers, family members and individuals with ID; Limitation of human resources-technical caregivers and project leaders;Other

preferences of intitution-techical Poor caregivers;

Communication problems

between caregivers and family members regarding the dynamization of PA-technical caregivers, family members and project leaders.

$\mathrm{N}=8$ family members (4 mothers, 3 fathers and a stepfather-a recruited couple, who responded separately); Age of children: 10 to 18 years old (6 male; 1 female) Recruitment: support schools and clubs for people with ID in Glasgow.
Lack of information about adequate and inclusive PA; Social exclusion;

Fear of parents in relation to bullying;

Semi-structured study. family members; Duration: 20 to $55 \mathrm{~min}$.
Poor

(n)


Table 1. Cont.

\begin{tabular}{|c|c|c|c|c|c|c|}
\hline $\begin{array}{l}\text { Author, } \\
\text { Reference, } \\
\text { Country }\end{array}$ & Aims & Participants & Type of Study & $\begin{array}{l}\text { Evaluation } \\
\text { Techniques }\end{array}$ & Barriers to PA Practice & $\begin{array}{c}\text { Quality } \\
\text { Score }\end{array}$ \\
\hline $\begin{array}{l}\text { Salomon } \\
\text { et al. [23] }\end{array}$ & $\begin{array}{l}\text { Perception of } \\
\text { barriers and } \\
\text { facilitators to the } \\
\text { practice of PA and } \\
\text { healthy eating } \\
\text { (separately). }\end{array}$ & $\begin{array}{c}\mathrm{N}=14 ; \\
6 \text { renumbered } \\
\text { workers and } 8 \text { people } \\
\text { with ID; >60Y; } \\
\text { Recruitment: support } \\
\text { service for people } \\
\text { with ID. }\end{array}$ & $\begin{array}{l}\text { Qualitative } \\
\text { study. }\end{array}$ & $\begin{array}{l}\text { Semi-structured } \\
\text { interviews. }\end{array}$ & $\begin{array}{l}\text { Both groups: (i) aging; (ii) health } \\
\text { problems; (iii) lack of adapted } \\
\text { spaces; (iv) lack of inclusion; } \\
\text { ID group: (i) chronic diseases; (ii) } \\
\text { climatic conditions; } \\
\text { Group of workers (i) low } \\
\text { concentration; (ii) challenging } \\
\text { behaviors; iii) social stigma; (iv) } \\
\text { lack of adapted places; (v) sensory } \\
\text { issues (example: loud music in } \\
\text { spaces; (vi) limitation of financial } \\
\text { resources; (vii) limitation of } \\
\text { human resources. }\end{array}$ & Poor \\
\hline $\begin{array}{c}\text { Stanish } \\
\text { et al. [24] } \\
\text { USA }\end{array}$ & $\begin{array}{c}\text { Compare } \\
\text { pleasure with PA, } \\
\text { perceived } \\
\text { barriers, beliefs } \\
\text { and self-efficacy } \\
\text { between ID and } \\
\text { the general } \\
\text { population. }\end{array}$ & $\begin{array}{c}\mathrm{N}=98 ; \text { ID group } \\
\text { (N=38,3-21 years, } \\
\text { AA:16.8y); general } \\
\text { population group } \\
\text { (N = 60, 13-18y, } \\
\text { AA: 15.3y); } \\
\text { Recruitment: } \\
\text { agencies, } \\
\text { organizations and } \\
\text { schools to support } \\
\text { individuals with ID. }\end{array}$ & $\begin{array}{l}\text { Cross- } \\
\text { sectional } \\
\text { study. }\end{array}$ & $\begin{array}{l}\text { Structured } \\
\text { interview of } \\
33 \text { closed- } \\
\text { response items; } \\
\text { Duration: } 15 \text { to } \\
20 \mathrm{~min} .\end{array}$ & $\begin{array}{l}\text { ID group: (i) PA is difficult to } \\
\text { learn; (ii) lack of places to } \\
\text { practice PA. }\end{array}$ & Poor \\
\hline
\end{tabular}

AA: Average age; ID: Intellectual disability; Min: Minutes; N: Participants; PA: Physical activity; Y: years; DS: Down syndrome.

\subsection{Evaluation of the Quality of the Studies}

The Downs and Black Scale [25] was used to assess the methodological quality of studies. This scale consists of 27 items, punctuated with "one value" or "zero", characterizing the different parts of an article. The methodological quality of studies was independently assessed by two researchers (MJ and DP). The results obtained by both were compared and discussed, so that a consensus was reached. When consensus was not possible, a third researcher was invited to collaborate (AV). The scale's scoring intervals received corresponding levels of quality: excellent (26-28); good (20-25); fair (15-19); and poor $(\leq 14)$. However, as fifteen questions (questions $8,10-12,14-17$ and 21-27) were not applicable to all studies analyzed, they were removed. The scale, after being modified, had a maximum of 12 points in relation to the original.

In the present study, no study was excluded due to a low quality score.

\section{Results}

\subsection{Selection of Studies}

The initial search carried out in the four databases revealed a total number of 159 articles identified. In the first phase, and after reading the titles and abstracts, seven potentially relevant studies were identified for the next phase. Considering the applicability of inclusion and exclusion criteria previously defined for this systematic review, and after the complete reading of the articles, a sample of five studies was considered for full analysis.

Figure 1 represents the PRISMA flowchart diagram for the selection of studies in this systematic review.

\subsection{Methodological Quality}

The methodological quality of the studies was assessed as poor in all studies; however, no study was excluded due to the low quality score. The quality classification is shown in Table 1. 


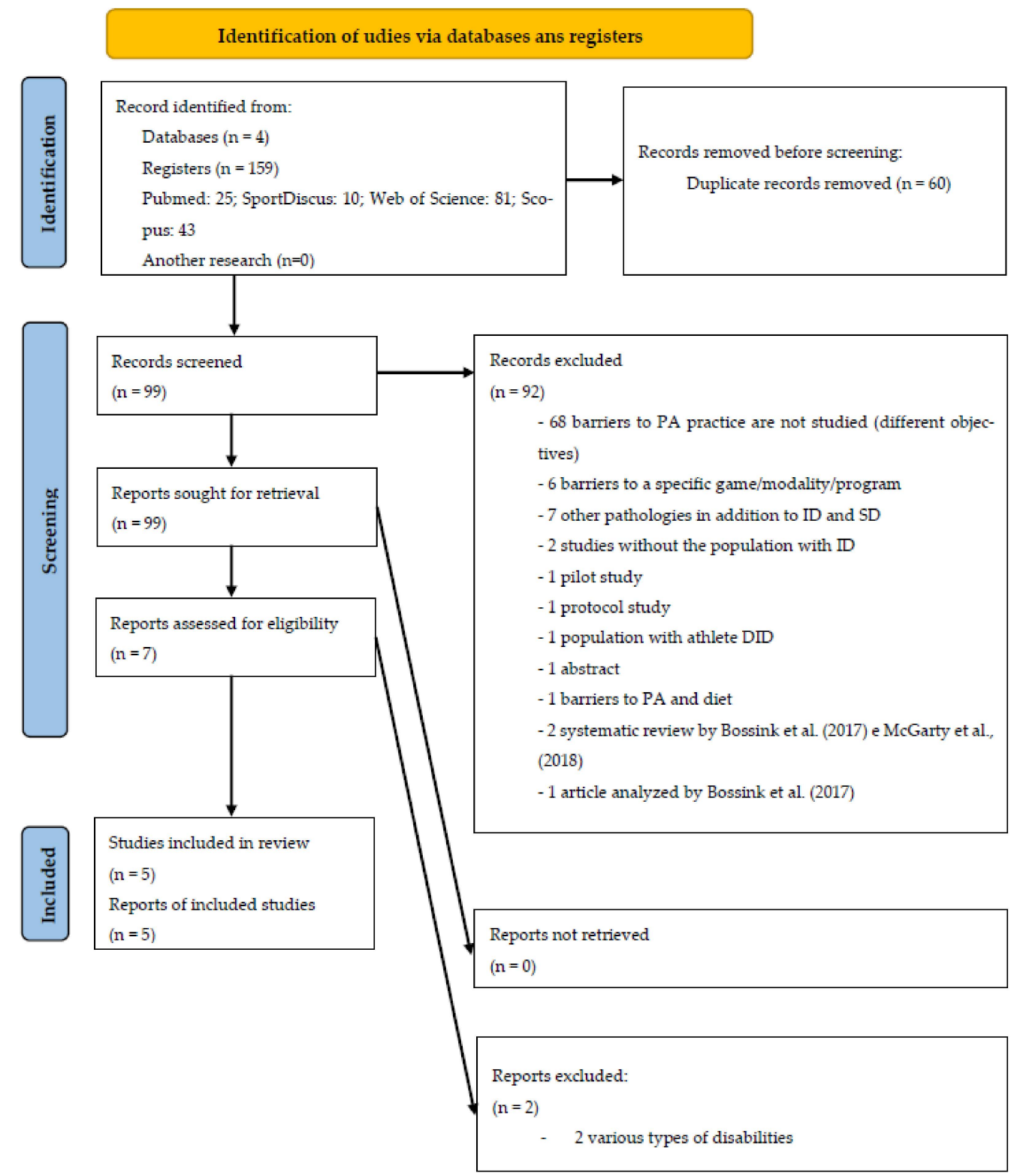

Figure 1. PRISMA flow diagram illustrating each phase of the search and selecting process.

\subsection{Characteristics of the Studies}

Table 1 presents the characteristics, results and methodological quality of the studies included for final review.

\subsection{Origin}

Through the systematic review process, we identified five studies: three other studies from Europe (Italy [20], United Kingdom [21,22]), one from Oceania (Australia [23]) and another from North America (USA [24]). Although all studies use a qualitative methodology, we can see different designs.

\subsection{Type of Studies}

Two exploratory studies, two qualitative studies and one cross-sectional study were included. 


\subsection{Participants}

From a total of 181 participants, only 56 were individuals with ID. All the others participants were family members, technical caregivers or project leaders. Three studies underlined the importance of self-reported responses by individuals with ID [21,23,24]. All studies emphasize the importance of the perception of PA participation barriers in individuals who are supported by institutions that support people with disabilities. At the same time, some studies analyzed facilitators and recommendations for participating in PA. In terms of age group, one of the studies does not refer the age of the individuals with ID [21], three other studies have samples from young adolescents [20,22,24] and one study is focused on elderly participants [23].

\subsection{Evaluation Techniques}

All studies used as instrument or evaluation technique, a semi-structured or rigid interview; however, in two studies we do not have information on the questions or topics. Cartwright et al. [21] used different topics for different groups: seven for individuals with ID themselves, seven for family members and caregivers and four topics for the project leaders. McGarty et al. [22] used four main topics in the semi-structured interview (to family members). Stanish et al. [24] chose to use the questionnaire and passed it on to the participants in the form of a rigid interview, which is easy to answer, in both groups of participants. Two studies did not report the duration of the interview, which lasted a maximum of $55 \mathrm{~min}$ in two studies [20,22] and $20 \mathrm{~min}$ in another study [24].

\subsection{Barriers to PA Pratice}

Taking into account the results of the studies of this systematic review, we can classify the following barriers to PA participation into five different factors, as shown in Table 2.

Table 2. Barriers to PA practice divided by different factors.

\begin{tabular}{ll}
\hline Personal & $\begin{array}{l}\text { Characteristics of the disability itself (physical, physiological and psychological); acceptance of inactive lifestyles; } \\
\text { aging; health problems; lack of concentration; challenging behaviors. }\end{array}$ \\
\hline $\begin{array}{l}\text { Family } \\
\text { members }\end{array}$ & $\begin{array}{l}\text { Parents' concerns (bullying, among others); acceptance of inactive lifestyles; communication problems with } \\
\text { technical caregivers; lack of time to engage in PA with their children. }\end{array}$ \\
\hline & $\begin{array}{l}\text { Acceptance of inactive lifestyles; lack of information on adapted PA; lack of adapted PA programs; lack of } \\
\text { inclusive opportunities; lack of technicians specialized in adapted PA; lack of places to practice PA; limitation of } \\
\text { human resources; other preferences of the institution providing support services; communication problems } \\
\text { between family members and caregivers; social exclusion (stigma and lack of understanding in relation to } \\
\text { disability); lack of support; sensory issues (music too loud in training places); difficulties in transportation } \\
\text { (high costs, lack of transport). }\end{array}$ \\
\hline Financial & Limited financial resources. \\
\hline Environmental & Climate.
\end{tabular}

Complementarily to previous results, in a study assessing ID athletes' perceptions about barriers to PA participation [26], social barriers were also identified, namely the lack of adapted transport, in addition to environmental barriers specific to their condition such as travel time to the training site and the time it takes to arrive at the next appointments. As athletes, they were expected to adopt more active lifestyles and have already overcome a set of a posteriori barriers.

Regarding the perception of PA participation barriers in individuals with ID that received support from institutions, they can be divided by personal, social and environmental factors (Table 3), which we highlight: 
Table 3. Barriers to PA practice in the perception of individuals with ID.

\begin{tabular}{cl}
\hline \multirow{3}{*}{ Personal } & (i) Preference for inactive lifestyles [21]; \\
& (ii) Aging [23]; \\
& (iii) Health problems [23]. \\
\hline & (i) Lack of adapted spaces [23]; \\
Social & (ii) Lack of inclusion [23]; \\
& (iii) Lack of places to practice PA [24]; \\
& (iv) Lack of adapted PA [24]. \\
\hline Environmental & (i) Adverse weather conditions [23]. \\
\hline
\end{tabular}

On the other hand, Table 4 shows the PA participation barriers from the perspective of the interviewed family members.

Table 4. Barriers to PA practice in the perception of family members.

\begin{tabular}{cl}
\hline Personal & (i) Characteristics of the disability itself [20,22]. \\
& (i) Lack of specialists in adapted PA [20]; \\
& (ii) Lack of adapted PA programs [20]; \\
& (iii) Lack of inclusive programs [20,22]; \\
Social & (iv) Difficulties in transportation [20]; \\
& (v) Lack of information about adequate and inclusive PA [22]; \\
& (vi) Social exclusion [22]; \\
& (vii) Lack of support [22]; \\
& (viii) Stigma and lack of understanding of disability [22]. \\
& (i) Parents' concerns [20,22]; \\
Family members & (ii) Lack of time for parents to engage in PA with their children [20]; \\
& (iii) Acceptance of children's inactive lifestyles [21]; \\
(iv) Communication problems between family members and caregivers [21].
\end{tabular}

Analyzing the technical caregivers' perceived PA participation barriers, we highlight, in Table 5, the following barriers:

Table 5. Barriers to PA practice in the perception of technical caregivers.

\begin{tabular}{ll}
\hline & (i) Aging [23]; \\
Personal & (ii) Health problems [23]; \\
& (iii) Low concentration capacity [23]; \\
& (iv) Challenging behaviors [23]. \\
& (i) Lack of adapted spaces [23]; \\
& (ii) Lack of inclusion [23]; \\
& (iii) Stigma [23]; \\
& (iv) Sensory issues [23]; \\
& (v) Lack of human resources in institutions; \\
& (vi) Acceptance of inactive lifestyles [21,23]; \\
& (vii) Other preferences of technical caregivers and institutions [21]; \\
& (viii) Communication problems between family members and caregivers [21]. \\
\hline Financial & (i) Limitation of financial resources [23]. \\
\hline
\end{tabular}

The present study also included an article that analyzed the perception of project leaders about PA participation barriers in the population with ID [21], stating that such barriers are related to the following social factors, as shown in Table 6. 
Table 6. Barriers to PA practice in the perception of project leaders.

\begin{tabular}{|c|c|c|}
\hline \\
\hline Social & \multicolumn{2}{|c|}{$\begin{array}{l}\text { (i) Limitation of human resources; } \\
\text { (ii) Communication problems between family members and caregivers. }\end{array}$} \\
\hline \multicolumn{3}{|c|}{$\begin{array}{l}\text { The studies included in this systematic review also provide some recommendations } \\
\text { for reducing and attenuating barriers, which are presented in Table } 7 \text {. }\end{array}$} \\
\hline Greater participation by families & & Alesi [20]: McGar \\
\hline Creating more adapted sports offerings & & Alesi [20] \\
\hline Organize environments that aim to stimulate & ts participation & Alesi [20] \\
\hline $\begin{array}{l}\text { Organizational change, in the sense of giving } \\
\text { lives of people with ID }\end{array}$ & ter importance to PA in the & Cartwright et al. [21] \\
\hline $\begin{array}{l}\text { Local authorities or organizations to increase } \\
\text { finance services }\end{array}$ & ffer of adapted PA and & Cartwright et al. [21]; Stanish et al. [25] \\
\hline Pay more attention to the sporting preference & ndividuals & Cartwright et al. [21] \\
\hline Greater cooperation between all parties in or & promote PA & Cartwright et al. [21] \\
\hline More and better support and information & & McGarty et al. [22] \\
\hline Personal training & & Stanish et al. [24] \\
\hline PA instruction carried out carefully and with & & Stanish et al. [24] \\
\hline Development of group activities & & Stanish et al. [24] \\
\hline
\end{tabular}

\section{Discussion}

The major purpose of this study is to increase knowledge for a better understanding of the perceived barriers of physical activity participation in individuals with ID, identify and discuss the reasons and factors associated with those participation barriers and to identify appropriate strategies to be used by professionals based on the perception of individuals with ID, their families and their technical caregivers.

The social barriers to PA participation are those that present a greater set of topics. In the studies included in the present systematic review, individuals with ID themselves and project leaders are the groups that perceive the least barriers, unlike family members and technical caregivers. In the same sense, a behavioral change in the direct support from professionals is suggested in order to promote PA among individuals with ID [27], increasing interpersonal interaction between both stakeholders as well as the commitment to encourage, adopt and maintain PA participation [28]. On the other end, family members recognize that they are the main barrier to PA participation, since they describe themselves as overprotective of their children, given their characteristics [20]. They must mitigate these attitudes and stimulate PA participation since PA patterns in childhood are seen as relevant predictors of PA participation in adulthood [29,30]. They are preponderant in the process of starting and adhering to PA participation in its quantity, duration and complexity [31,32].

We also highlight those topics such as the characteristics of the disability itself, lack of spaces and adapted activities, which are referenced by the various studies included in the systematic review. The previous reported results are transversal to other types of disability. For motor disabilities, Jaarsma et al. [33] highlighted the following barriers to PA practice: (i) characteristics of the disability itself; (ii) health; (iii) lack of facilities for the practice of PA; (iv) transportation; (v) accessibility. Additionally, Marmeleira et al. [34] identified a set of barriers in the visually impaired population: (i) problems on sidewalks; (ii) lack of adapted facilities; (iii) lack of support from public entities; (iv) need for a guide; (v) lack of adapted PA supply; (vi) lack of security in existing facilities. Tsai and Fung [35] reported the following barriers to PA participation in the hearing-impaired population: 
(i) uncomfortable feelings with society's negative attitudes towards disability; (ii) lack of adapted information; (iii) physical discomfort; (iv) lack of physical fitness; (v) lack of direction; (vi) interpersonal restrictions; (vii) lack of adapted facilities. These barriers lead us to the conclusion that there is an important need to create physical exercise programs that are as personalized and adapted as possible to individuals' needs.

Our study included articles from various age groups, including most perceived barriers to PA participation at different ages, with the exception of aspects inherent to aging, climate, sensory issues and limited human resources that are only identified by the elderly population [23].

The results of the present study confirm the existence of clear barriers to PA participation in individuals with ID at all levels. Some of them have been identified in the literature for quite a long time, as is the case for Messent et al. [36], where intrinsic and extrinsic barriers are mentioned, or in more recent studies, as is the case for Bossink et al. [13], where 14 personal barriers and 23 environmental barriers were identified, and McGarty and Melville's [14] study that, despite asking only family members, suggested that barriers to PA participation were related to three factors: (i) family members; (ii) personal; and (iii) social. All barriers found through the present study have already been identified and mentioned by previous systematic reviews. However, based on Bossink et al.'s study [13], the barriers seem to have attenuated/decreased, since in this systematic review there were no topics such as: (i) individual fears; (ii) lack of motivation; (iii) anxiety on the part of the technicians (fear of doing something wrong). Aiming to increase the regular practice of PA, the results of this systematic review can be seen to indicate that recommendations/strategies are being put into practice, and this may be at the origin of the decrease in some barriers. Some studies analyzed in this systematic review provide a set of strategies/recommendations [20-22,24] that can be seen as contributions to mitigate/decrease barriers to PA practice that must be taken into account. This fact may lead individuals to adopt more active lifestyles, which lead us back to the Ecological Model for Health Promotion [37], in a perspective that can support the process of behavioral change and promote health (Table A1). The Ecological Model for Health Promotion [37] emphasizes the importance of social environments for health promotion and requires more active participation by various stakeholders, where the Personal, Interpersonal, Organizational, Community and Public Policy factors have a fundamental role in the structuring, promotion and implementation of PA programs, reducing and attenuating the barriers to the practice of PA and highlighting the very interventional role of the organization in this process.

A limitation of this systematic review is the fact that the studies selected for analysis did not separate the barriers by degree of ID (mild, moderate, severe or profound), because their impact may be differentiated since they require different support and physical inactivity is greater as the degree of ID increases. However, self-reports are important, although we are aware that not all individuals have the capacity to respond. That said, in future studies, it is important to analyze the barriers to the practice of PA at different degrees/levels, even if through the perception of third parties, so that the support/strategies/interventions are the most adapted possible.

Accordingly, the analysis of barriers to the practice of PA, by age and gender, should also be taken into account in future studies. No studies were found with the Portuguese population, which should be the object of study in future works. Future works should also analyze barriers to the degree of disability (mild, moderate, severe and profound ID) separately.

\section{Conclusions}

The disabled person faces a set of barriers to the practice of PA. Specifically in ID, the main barriers to PA practice, perceived by individuals with ID themselves, their families, caregivers/technicians or even from the perspective of project leaders, can be systematized 
into personal factors (6 topics), family members (4 topics), social (13 topics), financial (1 topic) and environmental (1 topic).

Since the last published systematic review, the number of perceived barriers to the practice of PA by individuals with ID has decreased. This fact may presuppose basic work carried out, taking into account the strategies and recommendations that have been presented, aiming to promote the practice of PA and therefore influencing this change.

The present work reinforces the existence of a set of barriers to the practice of PA by several interested parties, being a useful tool for researchers and professionals in the process of structuring, promoting and implementing PA programs among individuals with ID, which should be as adapted as possible to the individual and their preferences in order to contribute to an increase in healthy lifestyles and to an improvement in physical fitness, health and quality of life.

Author Contributions: Conceptualization, M.J. and A.S.V.; methodology, M.J., A.S.V. and T.B.; software, M.J.; validation, A.S.V., R.A., R.M., J.P.F. and T.B.; formal analysis, A.S.V., D.P., R.A., R.M., J.P.F. and T.B.; investigation, M.J. and D.P.; resources, M.J. and D.P.; data curation, M.J. and D.P.; writing—original draft preparation, M.J.; writing—review and editing, M.J., A.S.V., D.P., R.A., R.M., J.P.F. and T.B.; visualization, A.S.V., D.P., R.A., R.M., J.P.F. and T.B.; supervision, A.S.V., R.A., R.M., J.P.F. and T.B.; project administration, M.J.; funding acquisition, M.J., R.A. and R.M. All authors have read and agreed to the published version of the manuscript.

Funding: Portuguese Foundation for Science and Technology, I.P., Grant/Award Number UIDP/ $04748 / 2020$.

Institutional Review Board Statement: Not applicable.

Informed Consent Statement: Not applicable.

Data Availability Statement: Additional data are available upon request to the author for correspondence.

Conflicts of Interest: The authors have no conflict of interest to disclose.

\section{Appendix A}

Table A1. Relationship between Ecological Model for Health Promotion and study recommendations.

\begin{tabular}{|c|c|c|c|c|c|c|}
\hline & Personal & Interpersonal & Organizational & Community & Public Policy & Author \\
\hline $\begin{array}{l}\text { Greater participation } \\
\text { by families }\end{array}$ & & $X$ & & & & $\begin{array}{c}\text { Alesi [20]; } \\
\text { McGarty et al. [22]; } \\
\text { Stanish et al. [24] }\end{array}$ \\
\hline $\begin{array}{l}\text { Creating more adapted } \\
\text { sports offerings }\end{array}$ & & & $X$ & $X$ & & Alesi [20] \\
\hline $\begin{array}{l}\text { Organize environments } \\
\text { that aim to stimulate } \\
\text { sports participation }\end{array}$ & & & $X$ & $X$ & $X$ & Alesi [20] \\
\hline $\begin{array}{l}\text { Organizational change, } \\
\text { in the sense of giving } \\
\text { greater importance to } \\
\text { PA in the lives of } \\
\text { people with ID }\end{array}$ & & & $X$ & & & Cartwright et al. [21] \\
\hline $\begin{array}{l}\text { Local authorities or } \\
\text { organizations to } \\
\text { increase the offer of } \\
\text { adapted PA and } \\
\text { finance services }\end{array}$ & & & $X$ & $x$ & $x$ & $\begin{array}{l}\text { Cartwright et al. [21]; } \\
\text { Stanish et al. [24] }\end{array}$ \\
\hline
\end{tabular}


Table A1. Cont.

\begin{tabular}{|c|c|c|c|c|c|c|}
\hline & Personal & Interpersonal & Organizational & Community & Public Policy & Author \\
\hline $\begin{array}{l}\text { Pay more attention to } \\
\text { the sporting } \\
\text { preferences of } \\
\text { individuals }\end{array}$ & & $X$ & $X$ & $X$ & $X$ & Cartwright et al. [21] \\
\hline $\begin{array}{l}\text { Greater cooperation } \\
\text { between all parties in } \\
\text { order to promote PA }\end{array}$ & $X$ & $X$ & $X$ & $X$ & $X$ & Cartwright et al. [21] \\
\hline $\begin{array}{l}\text { More and better } \\
\text { support and } \\
\text { information }\end{array}$ & & $x$ & $X$ & $x$ & $x$ & McGarty et al. [22] \\
\hline Personal training & & $X$ & $X$ & & & Stanish et al. [24] \\
\hline $\begin{array}{l}\text { PA instruction carried } \\
\text { out carefully and } \\
\text { with quality; }\end{array}$ & & $x$ & & & & Stanish et al. [24] \\
\hline $\begin{array}{c}\text { Development of group } \\
\text { activities }\end{array}$ & & $x$ & $X$ & $X$ & $X$ & Stanish et al. [24] \\
\hline
\end{tabular}

\section{References}

1. American Psychiatric Association. Diagnostic and Statistical Manual of Mental Disorders (DSM-5); American Psychiatric Association: Washington, DC, USA, 2013.

2. Dairo, Y.M.; Collett, J.; Dawes, H.; Oskrochi, G.R. Physical activity levels in adults with intellectual disabilities: A systematic review. Prev. Med. Rep. 2016, 4, 209-219. [CrossRef]

3. Hsieh, K.; Hilgenkamp, T.I.M.; Murthy, S.; Heller, T.; Rimmer, J.H. Low levels of physical activity and sedentary behavior in adults with intellectual disabilities. Int. J. Environ. Res. Public Health 2017, 14, 1503. [CrossRef]

4. World Health Organization. Guidelines on Physical Activity and Sedentary Behaviour; World Health Organization WHO: Geneva, Switzerland, 2020.

5. Borji, R.; Zghal, F.; Zarrouk, N.; Sahli, S.; Rebai, H. Individuals with intellectual disability have lower voluntary muscle activation level. Res. Dev. Disabil. 2014, 35, 3574-3581. [CrossRef]

6. Chow, B.C.; Choi, P.H.N.; Huang, W.Y.J. Physical Activity and Physical Fitness of Adults with Intellectual Disabilities in Group Homes in Hong Kong. Int. J. Environ. Res. Public Health 2018, 15, 1370. [CrossRef] [PubMed]

7. Gawlik, K.; Zwierzchowska, A.; Manowska, B.; Celebańska, D. Aerobic capacity of adults with intellectual disabilities. Ann. Agric. Environ. Med. 2016, 24, 117-120. [CrossRef] [PubMed]

8. De Winter, C.F.; Bastiaanse, L.P.; Hilgenkamp, T.I.M.; Evenhuis, H.M.; Echteld, M.A. Cardiovascular risk factors (diabetes, hypertension, hypercholesterolemia and metabolic syndrome) in older people with intellectual disability: Results of the HA-ID study. Res. Dev. Disabil. 2012, 33, 1722-1731. [CrossRef] [PubMed]

9. Bartlo, P.; Klein, P.J. Physical activity benefits and needs in adults with intellectual disabilities: Systematic review of the literature. Am. J. Intellect. Dev. Disabil. 2011, 116, 220-232. [CrossRef] [PubMed]

10. Pestana, M.B.; Barbieri, F.A.; Vitório, R.; Figueiredo, G.A.; Mauerberg de Castro, E. Efeitos do Exercício Físico para Adultos com Deficiência Intelectual: Uma revisão sistemática. J. Phys. Educ. 2018, 29, e2920. [CrossRef]

11. Ptomey, L.T.; Szabo, A.N.; Willis, E.A.; Gorczyca, A.M.; Greene, J.L.; Danon, J.C.; Donnelly, J.E. Changes in cognitive function after a 12-week exercise intervention in adults with Down syndrome. Disabil. Health J. 2018, 11, 486-490. [CrossRef] [PubMed]

12. Calders, P.; Elmahgoub, S.; Roman de Mettelinge, T.; Vandenbroeck, C.; Dewandele, I.; Rombaut, L.; Vandevelde, A.; Cambier, D. Effect of combined exercise training on physical and metabolic fitness in adults with intellectual disability: A controlled trial. Clin. Rehabil. 2011, 25, 1097-1108. [CrossRef]

13. Bossink, L.W.M.; van der Putten, A.A.; Vlaskamp, C. Understanding low levels of physical activity in people with intellectual disabilities: A systematic review to identify barriers and facilitators. Res. Dev. Disabil. 2017, 68, 95-110. [CrossRef]

14. McGarty, A.M.; Melville, C.A. Parental perceptions of facilitators and barriers to physical activity for children with intellectual disabilities: A mixed methods systematic review. Res. Dev. Disabil. 2018, 73, 40-57. [CrossRef] [PubMed]

15. Moher, D.; Shamseer, L.; Clarke, M.; Ghersi, D.; Liberati, A.; Petticrew, M.; Shekelle, P.; Steward, L.A.; PRISMA-P Group. Preferred reporting items for systematic review and meta-analysis protocols (PRISMA-P) 2015 statement. Syst. Rev. 2015, 4, 1. [CrossRef]

16. Page, M.J.; McKenzie, J.E.; Bossuyt, P.M.; Boutron, I.; Hoffmann, T.C.; Mulrow, C.D.; Shamseer, L.; Tetzlaff, J.M.; Akl, E.A.; Brennan, S.E.; et al. The PRISMA 2020 statement: An updated guideline for reporting systematic reviews. BMJ 2021, $372, \mathrm{n} 71$. [CrossRef] [PubMed] 
17. Bento, T. Revisões sistemáticas em desporto e saúde: Orientações para o planeamento, elaboração, redação e avaliação. Motricidade 2014, 10, 107-123. [CrossRef]

18. Methley, A.M.; Campbell, S.; Chew-Graham, C.; McNally, R.; Cheraghi-Sohi, S. PICO, PICOS and SPIDER: A comparison study of specificity and sensitivity in three search tools for qualitative systematic reviews. BMC Health Serv. Res. 2014, 14, 579. [CrossRef]

19. Nang, C.; Piano, B.; Lewis, A.; Lycett, K.; Woodhouse, M. Using The PICOS Model to Design and Conduct a Systematic Search A Speech Pathology Case Study. In Proceedings of the ECU Research Week, Perth, Australia, 14-18 September 2015 ; p. 51.

20. Alesi, M. Investigating Parental Beliefs Concerning Facilitators and Barriers to the Physical Activity in Down Syndrome and Typical Development. SAGE Open 2017, 7, 215824401668779. [CrossRef]

21. Cartwright, L.; Reid, M.; Hammersley, R.; Walley, R.M. Barriers to increasing the physical activity of people with intellectual disabilities. Br. J. Learn. Disabil. 2017, 45, 47-55. [CrossRef]

22. McGarty, A.M.; Westrop, S.C.; Melville, C.A. Exploring parents' experiences of promoting physical activity for their child with intellectual disabilities. J. Appl. Res. Intellect. Disabil. 2021, 34, 140-148. [CrossRef]

23. Salomon, C.; Whittle, E.; Bellamy, J.; Evans, E.; Teasdale, S.; Samaras, K.; Ward, P.B.; Hsu, M.; Trollor, J. A qualitative exploration of barriers and enablers of healthy lifestyle engagement for older Australians with intellectual disabilities. Res. Pract. Intellect. Dev. Disabil. 2019, 6, 182-191. [CrossRef]

24. Stanish, H.I.; Curtin, C.; Must, A.; Phillips, S.; Maslin, M.; Bandini, L.G. Physical Activity Enjoyment, Perceived Barriers, and Beliefs Among Adolescents with and Without Intellectual Disabilities. J. Phys. Act. Health 2016, 13, 102-110. [CrossRef]

25. Downs, S.H.; Black, N. The feasibility of creating a checklist for the assessment of the methodological quality both of randomised and non-randomised studies of health care interventions. J. Epidemiol. Community Health 1998, 52, 377-384. [CrossRef]

26. Abellán, J.; Januário, N. Barreras, facilitadores y motivos de la práctica deportiva de deportistas con discapacidad intelectual. Psychol. Soc. Educ. 2017, 9, 419-431. [CrossRef]

27. Bossink, L.W.M.; van der Putten, A.A.J.; Vlaskamp, C. Physical-activity support for people with intellectual disabilities: A theoryinformed qualitative study exploring the direct support professionals' perspective. Disabil. Rehabil. 2020, 42, 3614-3620. [CrossRef] [PubMed]

28. Chow, B.C.; Choi, P.H.N.; Huang, W.Y.; Pan, C.-Y. Promoting Physical Activity in Group Home Settings: Staff Perspectives through a SWOT Analysis. Int. J. Environ. Res. Public Health 2020, 17, 5805. [CrossRef]

29. Hartman, E.; Smith, J.; Westendorp, M.; Visscher, C. Development of physical fitness in children with intellectual disabilities. J. Intellect. Disabil. Res. 2015, 59, 439-449. [CrossRef] [PubMed]

30. Telama, R.; Yang, X.; Viikari, J.; Välimäki, I.; Wanne, O.; Raitakari, O. Physical activity from childhood to adulthood: A 21-year tracking study. Am. J. Prev. Med. 2005, 28, 267-273. [CrossRef]

31. Temple, V.A.; Stanish, H.I. The feasibility of using a peer-guided model to enhance participation in community-based physical activity for youth with intellectual disability. J. Intellect. Disabil. 2011, 15, 209-217. [CrossRef]

32. Trost, S.G.; Kerr, L.M.; Ward, D.S.; Pate, R.R. Physical activity and determinants of physical activity in obese and non-obese children. Int. J. Obes. Relat. Metab. Disord. 2001, 25, 822-829. [CrossRef]

33. Jaarsma, E.A.; Dijkstra, P.U.; Geertzen, J.H.B.; Dekker, R. Barriers to and facilitators of sports participation for people with physical disabilities: A systematic review. Scand. J. Med. Sci. Sports 2014, 24, 871-881. [CrossRef]

34. Marmeleira, J.; Fernandes, J.; Ribeiro, N.; Teixeira, J.; Gutierres Filho, P. Barreiras para a prática de atividade física em pessoas com deficiência visual. Rev. Bras. Ciênc. Esporte 2018, 40, 197-204. [CrossRef]

35. Tsai, E.; Fung, L. Perceived constraints to leisure time physical activity participation of students with hearing impairment. Ther. Recreat. J. 2005, 39, 192-206.

36. Messent, P.R.; Cooke, C.B.; Long, J. Physical Activity, Exercise and Health of Adults with Mild and Moderate Learning Disabilities. Br. J. Learn. Disabil. 1998, 26, 17-22. [CrossRef]

37. McLeroy, K.R.; Bibeau, D.; Steckler, A.; Glanz, K. An ecological perspective on health promotion programs. Health Educ. Q. 1988, 15, 351-377. [CrossRef] [PubMed] 